\title{
Development of a Road Condition Information System using Augmented Reality Technology on Smartphones
}

\author{
Nur Wakhidah, Siti Asmiatun, Astrid Novita Putri
}

\begin{abstract}
Recently, accidents involving ground transportations are getting worse and more serious. Indonesian State Police (Korlantas POLRI) recorded the number of accidents in 2018 as many as 109,215 accidents. The number has incresed 4.69 percent compared to 2017 as many as 104,327 events. Road traffic accidents are caused by human error, the driver in this case. The driver's mistake is influenced by several factors, one of them is they cannot expect the road condition when they drive a vehicle at high speed. To solve this problem, drivers need information that can show road conditions. So, we present a new approach for detecting damaged roads by applying augmented reality technology. This research produces a road condition information system to help drivers get information about road conditions via smartphone. This system uses augmented reality technology with a markerless GPS Based Tracking method. The development of this system requires several stages such as collecting the data, data conversion, data classification, and views road condition. The researchers gathered the road condition data from the Public Work Department Semarang. This department itself undertakes a task to control the road condition in Semarang The trial of this system includes all drivers in Semarang city. Based on the results of the questionnaire responded to by 93 respondents, this test obtained an average value of $68 \%$. So this system gets a pretty good response from the driver. Through this system, all drivers can avoid the damaged road condition which can cause traffic-congested and accident.
\end{abstract}

Keywords: Augmented Reality, Road Condition, System, Information, Smartphone.

\section{INTRODUCTION}

$\mathrm{R}$ getting worse and more serious. Facts show that the major causes of death in Indonesia come from traffic accidents. Indonesian State Police the number of accidents in 2018 as many as 109,215 accidents. The number has incresed 4.69 percent compared to 2017 as many as 104,327 events [1]. Semarang City is a city with heavy traffic conditions. Road congestion generally occurs on national roads, which are the main connecting roads between Semarang City and other

Revised Manuscript Received on December 05, 2020.

* Correspondence Author

Nur Whakidah*, Department of Informatics Engineering, Semarang University, Semarang, Indonesia. Email: ida@usm.ac.id

Siti Asmiatun, Department of Informatics Engineering, Semarang University, Semarang, Indonesia. Email: siti.asmiatun@usm.ac.id

Astrid Novita Putri, Department of Informatics Engineering, Semarang University, Semarang, Indonesia. Email: astrid@usm.ac.id

(c) The Authors. Published by Blue Eyes Intelligence Engineering and Sciences Publication (BEIESP). This is an open access article under the CC BY-NC-ND license (http://creativecommons.org/licenses/by-nc-nd/4.0/) cities, both regionally and nationally [2]. Moreover, that condition creates traffic-congested to the city. Besides the bad traffic, the increased volume of traffic threatens people's lives. Driving a vehicle is a challenging job and this is supported by the fact that more than $80 \%$ of accidents are caused by driver error [3]. One of the factors that influence driver error is not being able to anticipate road conditions when the driver is driving at high speed. In handling road conditions, the government is obliged to facilitate road repairs, but the facts show that many roads have not been repaired. This is because repairs in some areas often take a long time to complete. So that the road conditions that are not right cause congestion and accidents for drivers. To overcome that problem, technology implementation is needed to give information to users when they want to pass unwell-road condition. Currently, the use of GPS services is increasingly phenomenal, especially in smartphones where signal receiving devices have been installed. Many applications are compatible with GPS services in smartphones and tracking systems can also be used with the built-in system [4]. On the other hand, There is also Augmented Reality (AR) technology as a technology that combines 2-dimensional and 3-dimensional virtual objects into a real environment and projects those objects displayed in real-time [5]. AR technology has developed rapidly and adopted mobile technology devices, such as smartphones and tablets [6][7]. On the other hand, Mobile AR (MAR) has a prospective AR scope and functionality so that it can present dynamic procedures for users when interacting with computers and digital information [8]. Due to the latest technical advances, augmented reality applications for smartphones using a digital compass and GPS can be made available to end-users [9] . In recent years the use of smartphones to find a certain location by applying the Global Positioning System (GPS) in order to track the road users or to provide route information has been increasing. Different interface technologies can be used to convey route information to users, such as mobile maps, voice, 3D, and images [10]. This is the concept of augmented reality maps carried out to provide a service to the road users. In practice, users can use smartphones to capture and display real-time video streams. The device will detect the geographical position, camera direction, and the tilt of the image captured by the device. The user will send the device capture to the server. The device will receive the search results and visually add the video stream according to the requested data [11]. Plenty of researches discussing augmented reality.

\section{Published By:}

Blue Eyes Intelligence Engineering and Sciences Publication

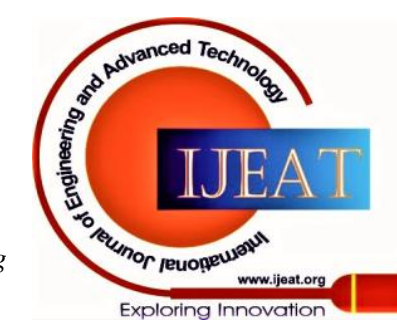




\section{Development of a Road Condition Information System using Augmented Reality Technology on Smartphones}

First, MA Muchtar et all state that Augmented Reality for Searching Potential Assets in Medan Using GPS Based Tracking has resulted in the cellular application providing tracking location and mapping is used to find the potential asset location in the users area by applying the augmented reality technology with markerless method.

This technology is applied in a cellular application utilizing GPS to track and to determine the users' smartphone coordinate so that it helps the users dynamically and easily found the potential asset location in the closest area based on the directed image on users' camera[12].

Previous research has explained that augmented reality can be applied to the navigation system. This technology can make it easier for users to perform various location-based jobs, such as navigation and finding places of interest.Augmented reality in navigation can improve safety while driving because users still see the road through the camera [13]. With applying the augmented reality and GPS, Te Lien Chou created a touring system application which provided road direction at Fu-Jen University [14]. In Sensors journal 2010, Javier Santana et all researched the augmented reality and virtual image as a guidance system of agricultural tractors. This system aimed to give tractor users information about land plotting in different colors [15].

So, we present a new approach for detecting damaged roads with applying augmented reality technology. This research produces a road condition information system to help drivers get information about road conditions via smartphone. The road condition information system uses augmented reality technology with a markerless GPS Based Tracking method. The novelty in this research is the implementation of augmented reality and GPS tracking to help road users obtaining real-time information on roads condition. Hopefully, Through this system, all drivers can avoid the damaged road condition which can cause traffic-congested and accident.

\section{REVIEW OF LITERATURE}

Currently, the Android system technology appears. With the Android system, smartphones are experiencing rapid development. Because through smartphones, users can access the internet anywhere and anytime. Augment reality technology can apply to the android system. That way, it can apply to various industrial fields and promote the formation of realistic industrial media through convergence with existing industries. It is expected to apply in various fields of industrial applications such as advertising, education, health care, mechanical assembly, military simulation, architectural navigation, and urban planning [16] [17][18]. Augmented reality types consist of marker and markerless augmented reality. The marker Augmented reality must use special markers to easier calculate coordinates. It can found in the ARtag library. ARtag and ARToolkit provide a fast way to calculate coordinates in the making real-time augmented reality system. Meanwhile, markerless augmented reality does not need a special marker. It will use the object information in the form of an image. This method detects the angle of the image object and displays it in a virtual form [19] [20] [21]. According to Madden, Markerless Augmented Reality uses the surface of a marker object as a tracking object because it supports the technique Pattern Recognition.
Markerless tracking requires the calculation of the position between the camera or user and the real world without any reference, only use natural feature points (edge, corner, line, or $3 \mathrm{D}$ model). The markerless method requires manual prior steps, as well as models or reference images for initialization. It's better the information need get from the object tracking [22]. Furthermore, there is a vuforia which can be used to implement the augmented reality. The vuforia platform uses excellent, stable, and efficient image recognition. It also provides several features to open a possibility in cellular ap-plication capability and to free a developer from a technical limit. The augmented reality-based vuforia SDK consists of a marker captured camera, tracking content, image conversion [23]. The Vuforia platform consists of a target management system component. The components are available on the developer portal (target manager), the target cloud database and target devices database, and the vuforia engine. The developer only needs to upload the input image for the tracking target. Vuforia SDK supports many target types such as 2D, 3D, multi-target configurations, cylinder targets for tracking images with cylinder surfaces, frame markers, and cloud recognition targets for tracking 1 million targets [24].

\section{METHODOLOGY}

\section{A. Proposed System}

This section discusses the system proposed to create the road condition information system. This system aims to provide real-time information to drivers about the condition of the damaged roads. Information is displayed with virtual images in real-time. And it functions to detect the closest damaged road to share with the road users. Figure 1 below shows two stages of the architecture system applied.

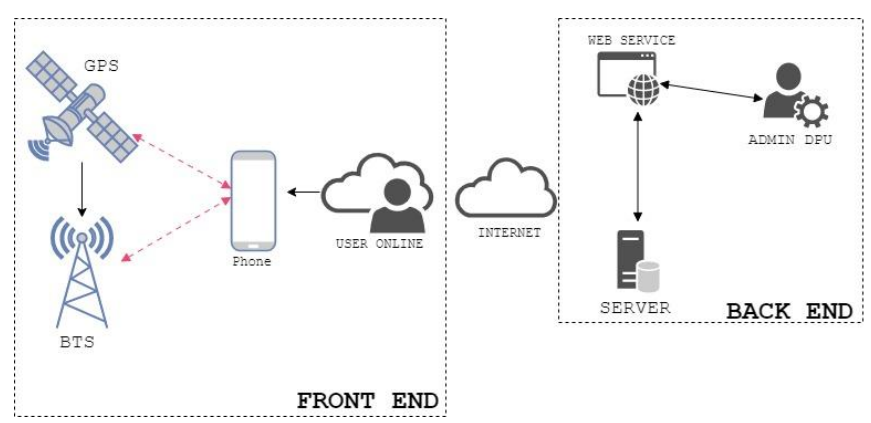

Fig.1. Architecture of Two-Tier System

When the road users have installed the road condition information system, this system functions as the interface between the drivers and the system. The interface system was built utilizing unity and vuforia SDK. Vuforia is the Augmented Reality cross-platform application development which its tracking and hardware working performance similar to a cell phone. Vuforia integration coming from unity allows the users in making a game and vision application [23]. On the backend side, researchers make use of the google maps API. Google provides an extensive source of code called Applications Programming Interface (API) for programmers An API consists of a set of data, structures, object classes,

Published By:

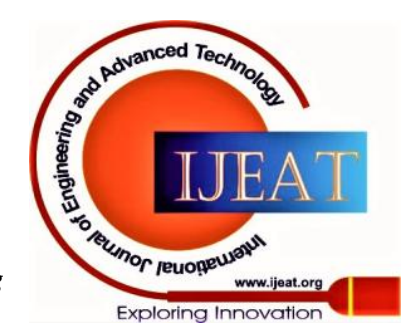


or functions using the programming language javascript, PHP, and others [25]. This technology can change the life of the end-user by providing a GIS navigation system so that the end-user does not worry about excessive information [26].

We develop this service to make a backend interface in which the public work department officers can upload the geographical coordinate data to the backend system. This data was obtained by utilizing the accelerometer to record the road condition in Semarang.

Google maps service can only identify decimal degree coordinates. So, the back-end system provides service in converting from UTM (Universal Transverse Mercator) coordinates to decimal degrees coordinates. So that the road condition can view through google maps. The converted data then will save in the server database. The system user will connect the front-end part to the backend part. And then the GPS recipient on a cellular device will connect to the GPS satellite to record the user's position. The front-end architecture is shown in figure 2 below.

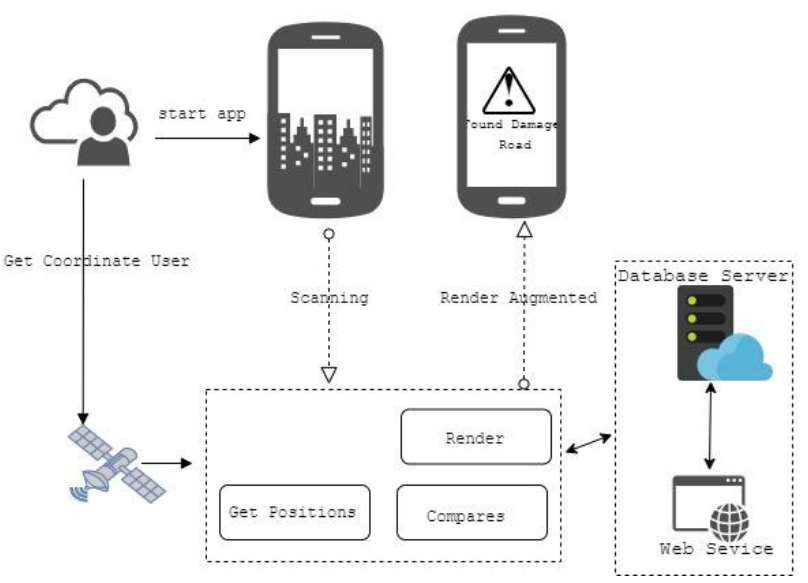

Fig.2. General Architecture (Frontend)

The Figure 2 above shows the frontend stages. When the user activates the system, the GPS will retrieve the drivers location data. Then the server will make a match with the location of the closest damaged road. The matching process will repeat until the system finds the closest damaged road coordinate. If found, the system will define the orientation and position to determine the location and virtual content position. Finally, the system will do rendering to show the virtual content. Virtual content is display to the frontend page in the form of 2D images.

\section{B. Algorithm}

The algorithm used for the classification of road conditions is Bayes' Theorem[27]. Conditional probabilities by the Bayes theorem can be calculated as :

$\mathrm{P}(\mathrm{c} \mid \mathrm{x})=\mathrm{P}(\mathrm{x} \mid \mathrm{c}) \times \mathrm{P}(\mathrm{c}) \div \mathrm{P}(\mathrm{x})$

$\mathrm{P}(\mathrm{c} \mid \mathrm{x})$, is the posterior probability of class given predictor

$\mathrm{P}(\mathrm{c})$, is the prior of class

$\mathrm{P}(\mathrm{x} \mid \mathrm{c})$ is the likelihood which is the probability of predictor given class

$\mathrm{P}(\mathrm{x})$ is prior probability of predictor
Bayes' theorem is a theorem that refers to the concept of conditional probability [28]. In general, the Bayes theorem can be denoted in equation (1). The advantage of this algorithm is simple but have high accuracy. The advantage of this algorithm is simple but have high accuracy.

In Bayes' theorem each condition is represented in attribute pairs <a1, a2, a3,> where a1 is a good condition, a2 is a moderate condition, a3 is a damaged condition. Where as $\mathrm{V}$ is a set of categories. At the time of classification, this method will produce the highest probability category $\left(\mathrm{V}_{\mathrm{MAP}}\right)$ by entering the $<\mathrm{a} 1$, a2, a3 $>$ attributes. The formula $\left(\mathrm{V}_{\mathrm{MAP}}\right)$ can be seen in equation (2)

$V_{\text {MAP }}=\underset{V_{j} \in v}{\operatorname{argmx}} \mathrm{P} V_{j} a_{1} a_{2} a_{a \ldots \ldots} \ldots a_{n}$

By using the Bayes theorem, equation (2) can be written as

$V_{M A P}=\underset{V_{j} \in v}{\operatorname{argmx}} \frac{p a_{1}, a_{2}, a_{3} m a_{n n} V_{j} x p V_{j}}{p a_{1}, a_{2}, a_{3} m a_{n}}$

The values $\mathrm{P}\left(a_{1}, a_{2}, a_{n} \ldots a_{n}\right)$ are constant for all $V_{j}$ so that equation (3) can also be expressed as equation (4)

$V_{\text {MAP }}=\underset{V_{j} \in \mathcal{D}}{\operatorname{argm} x} \mathrm{P} V_{j} a_{1} a_{2} a_{a \ldots \ldots x} a_{n} x P V_{j}$

The Bayes' theorem simplifies this by assuming that in each category, each attribute is free conditional on the other. In other words,

$P a_{1}, a_{2}, a_{a} \ldots a_{n} V_{j}={ }_{i}^{P} a_{i} V_{j}$

Then if equation (4) is substituted into equation (5), it will produce

$V_{\text {MAP }}=\underset{V_{j} \in v}{\operatorname{argmx}} \mathrm{P} V_{j} x_{i}^{P} a_{i} V_{j}$

$P V_{j}$ and the probability attribute $a_{\mathrm{i}}$ for each category $\mathrm{P}$ (ai vj) are calculated at the time of training. Where,

$P V_{j}=\frac{\text { Data }_{i}}{\text { Training }}$

$P a_{i} V_{j}=\frac{n_{i}+1}{n+V}$

Where Data $_{\mathrm{i}}$ is the number of documents in category $\mathrm{j}$ and training is the amount of data used in the training process. Whereas $n_{i}$ is the number of occurrences of $a_{i}$ data in the $V_{j}$ category, and $\mathrm{V}$ is the number of $V_{j}$ categories in all training data.Then classification in this study is classify whether road conditions are safe or damage based on the measured features. The features include percentages good, light and heavly as shown in table 1 .

$\mathrm{P}($ safe $)=0,5$

$\mathrm{P}($ damage $)=0,5$

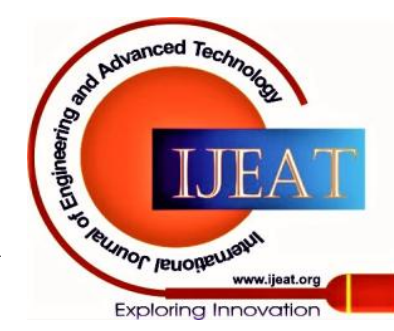




\section{Development of a Road Condition Information System using Augmented Reality Technology on Smartphones}

Bayes Classification for safe categories :

$P($ Safe $)=$

G(safe).G(low/safe).G(high/safe).L(low/safe).L(high/safe).

H(low/safe).H(high/safe)

$\mathrm{P}(\mathrm{safe})=0,5 \cdot 0,5 \cdot 0,5 \cdot 1 \cdot 0,5 \cdot 1 \cdot 0,5=0,03125$

Bayes Classification for damaged categories :

$P($ Damage $)=\quad G($ Damage $) \cdot G($ low $/ \quad$ Damage $) \cdot G($ high/ Damage).L(low/ Damage).L(high/ Damage). H(low/ Damage).H(high/ Damage)

$\mathrm{P}$ (damage) $=0,5 \cdot 0,5 \cdot 0,5 \cdot 0 \cdot 1 \cdot 0,5 \cdot 0,5=0$

Since posterior numerator is greater in the safe case, we predict the sample is safe. The results of road condition data classification will be implemented into augmented reality using unity and vuforia software. Implementation of the algorithm in this study consists of several stages as follows

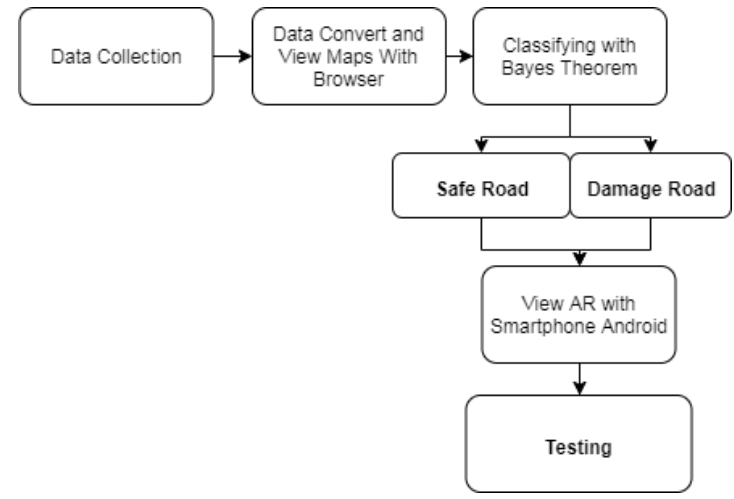

Fig.3. Proposed Flow Diagram

Description of image 3 as follows:

a. Data Collection is an activity carried out to collect data on road conditions in Semarang city

b. Data Convert is to convert data obtained from UTM (Universal Transverse Mercator) coordinate to decimal degree coordinates and displayed on maps

c. Classify data into two categories of damaged road and safe road using Naive Bayes algorithm

d. The classification results are display in the front-end part using smartphone

e. Evaluation activity using the questionnaire.

\section{RESULT AND DISCUSSION}

This road condition information system can detect the closest damaged road condition from the road drivers. This system consists of a front-end and back-end interface. The front-end interface is show for the drivers while the back-end interface is show for the Public Work Department officers. The development of this system requires several stages such as collecting the data, data conversion, data classification, and views road condition.

\section{A. Data Collection}

In this section, the researchers gathered the road condition data from the Public Work Department Semarang. This department itself undertakes a task to control the road condition in Semarang. Data collection via the RoadDroid application to record the road condition with utilizing accelerometer. The data is stored in excel form as follows:
Table- I: The Road Condition Data

\begin{tabular}{|c|c|c|c|c|c|c|}
\hline Street & Good & Light & Heavy & $\mathrm{X}$ & $\mathrm{Y}$ & Lbl \\
\hline $\begin{array}{l}\text { Barito } \\
\text { Street }\end{array}$ & 80,72 & 0 & 0 & $\begin{array}{r}43796 \\
3,003 \\
8 \\
\end{array}$ & $\begin{array}{r}9226 \\
558, \\
872 \\
\end{array}$ & Safe \\
\hline $\begin{array}{l}\text { Musi } \\
\text { Street }\end{array}$ & 0 & 27,78 & 72,22 & $\begin{array}{r}43784 \\
6,889 \\
9 \\
\end{array}$ & $\begin{array}{c}9229 \\
025, \\
361 \\
\end{array}$ & Damage \\
\hline $\begin{array}{l}\text { Progo } \\
1 \\
\text { Street } \\
\end{array}$ & 0 & 40,3 & 30 & $\begin{array}{r}43768 \\
7,886 \\
2 \\
\end{array}$ & $\begin{array}{r}9229 \\
556, \\
824 \\
\end{array}$ & Safe \\
\hline $\begin{array}{l}\text { Progo } \\
5 \\
\text { Street }\end{array}$ & 10,2 & 100 & 0 & $\begin{array}{r}43765 \\
6,974 \\
8\end{array}$ & $\begin{array}{r}9229 \\
677, \\
599\end{array}$ & Damage \\
\hline $\begin{array}{l}\text { Kaliso } \\
\text { dor } \\
\text { Street }\end{array}$ & 0 & 0 & 100 & $\begin{array}{r}43917 \\
1,860 \\
86\end{array}$ & $\begin{array}{r}9229 \\
511, \\
8801 \\
3\end{array}$ & Damage \\
\hline $\begin{array}{l}\text { Berua } \\
\text { ng } \\
\text { Street }\end{array}$ & 0 & 27,06 & 72,94 & $\begin{array}{r}43941 \\
9,995 \\
272 \\
\end{array}$ & $\begin{array}{r}9225 \\
763, \\
4395 \\
\end{array}$ & Damage \\
\hline $\begin{array}{l}\text { Unta } \\
\text { Street }\end{array}$ & 0 & 28,86 & 49,49 & $\begin{array}{r}43829 \\
8,698 \\
692\end{array}$ & $\begin{array}{r}9227 \\
704, \\
4657 \\
5\end{array}$ & Damage \\
\hline $\begin{array}{l}\text { Tangg } \\
\text { ul } \\
\text { Street }\end{array}$ & 0 & 0 & 100 & $\begin{array}{r}43913 \\
0,873 \\
898 \\
\end{array}$ & $\begin{array}{r}9225 \\
629, \\
1855 \\
\end{array}$ & Damage \\
\hline $\begin{array}{l}\text { Sleko } \\
\text { Street }\end{array}$ & 0 & 85,49 & 14,41 & $\begin{array}{r}43649 \\
8,662 \\
39 \\
\end{array}$ & $\begin{array}{r}9229 \\
729, \\
1770 \\
2 \\
\end{array}$ & Safe \\
\hline $\begin{array}{l}\text { Tamba } \\
\text { k Rejo } \\
\text { Makan } \\
\text { Street }\end{array}$ & 0 & 85,93 & 14,07 & $\begin{array}{r}43812 \\
4,733 \\
596 \\
\end{array}$ & $\begin{array}{r}9231 \\
669, \\
8664 \\
5 \\
\end{array}$ & Safe \\
\hline
\end{tabular}

Table 1 explained the result of the road condition taken from the data recording process. This data consisted of the road condition percentage were in good condition, light damage, or heavy damage. The column $\mathrm{x}$ and dy are UTM (Universal Transverse Mercator) coordinates where $\mathrm{x}$ is the start road and $\mathrm{y}$ is the end road

\section{B. Data Convert and View Maps With Browser}

Based on table 1 above, the coordinates need conversion from UTM (Universal Transverse Mercator) coordinates to decimal degrees coordinates. The backend interface provides this functionality shown in the following 4 figure:
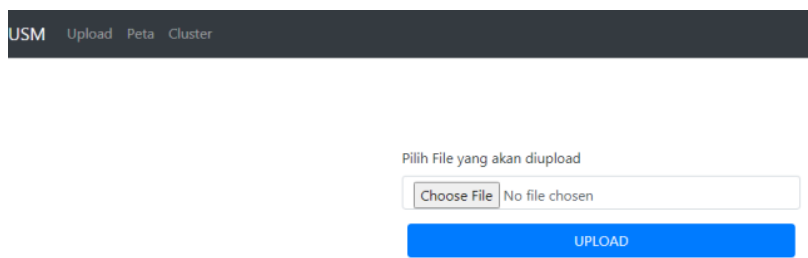

Fig.4. Data Upload

The shows figure 4 service to upload the road condition. Uploading data also functions to update the road condition in Semarang.

Published By:

Blue Eyes Intelligence Engineering and Sciences Publication 
Data uploaded into the system is excel data that contains the road condition (shown in table 1). The data conversion used to display classification results on google maps through this page.

\section{The Road Condition information System}

This section is the stage of building a front-end part. The front end is a section of information about road conditions. This section is accessed by drivers using a smartphone. At the front end, the system is create using unity and vuforia software with the $\mathrm{c}$ \# programming language. The system user can start detecting the road condition with clicking the button damaged road detection. Then GPS satellite will ask permission to access the smartphone position to get the coordinate point data. When the system user position is close to the damaged road, the warning will emerge. But when the system user position is far from the damaged road, the information will say it is safe.

Table- II: Experiment results

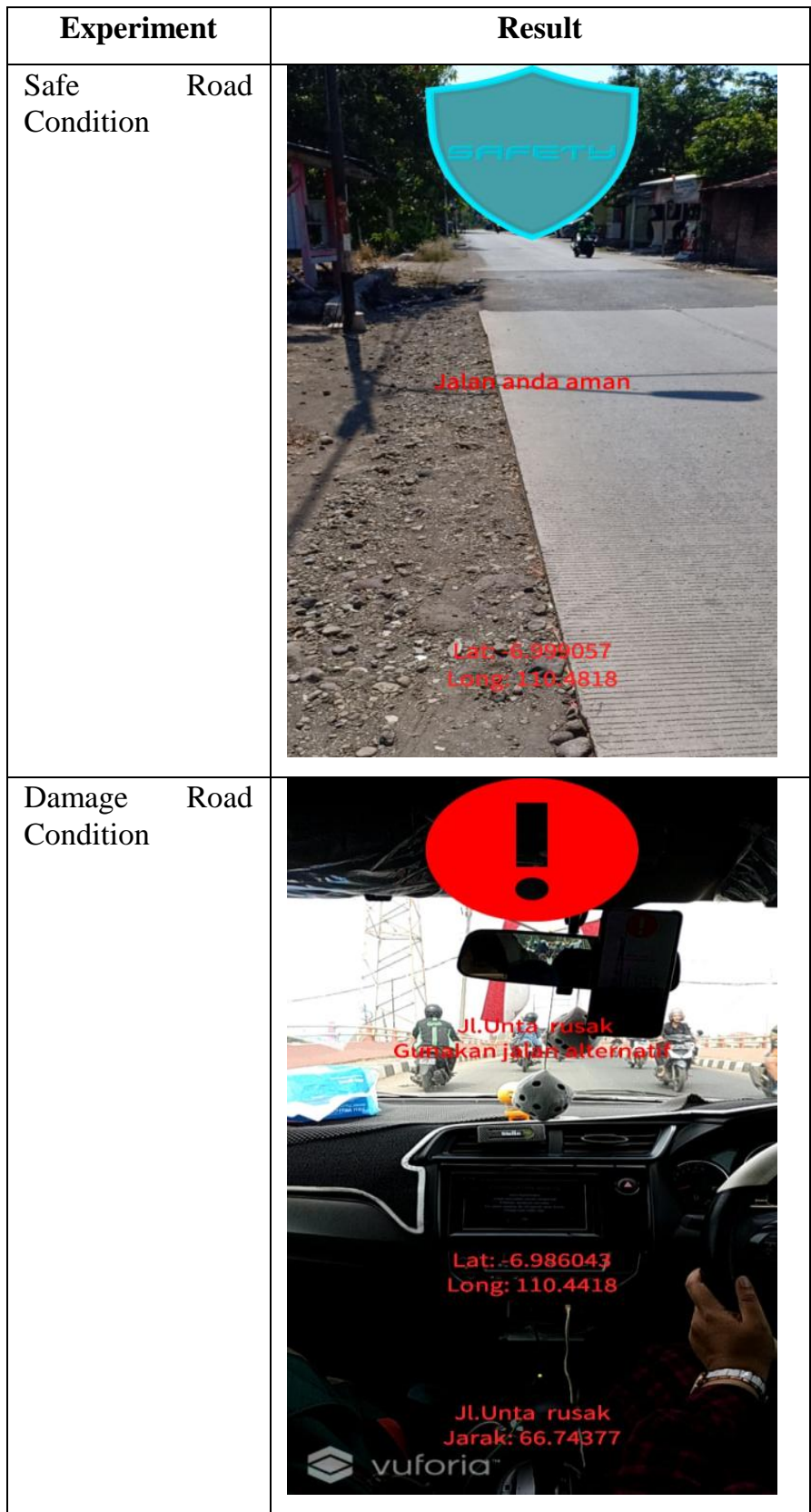

Table 2 shows that the system on the left shows the information on damaged roads, while the right side shows the road is safe or in good condition. In system development, this system has shortcomings in displaying virtual objects. Because the developer has not designed virtual objects where it can combine with real objects such as the concept of augmented reality.

\section{Testing}

This stage is testing. Testing in the form of a questionnaire aimed at the drivers. The questionnaire was used to measure the driver's response in the form of an average percentage. So it can use as a benchmark for the development of this system. The questionnaire contained five questions having the following measurement:

1. Strongly Agrees: 4,

2. Agree: 3,

3. Disagree: 2

4. Strongly Disagree: 1

The following was the questionnaire response:

Table- III: Questionnaire Result

\begin{tabular}{|c|c|c|c|c|c|c|}
\hline No & Questions & SD & $\begin{array}{l}\mathrm{Di} \\
\mathrm{S}\end{array}$ & Ag & $\begin{array}{l}\text { SA } \\
\text { g }\end{array}$ & Total \\
\hline 1 & $\begin{array}{l}\text { Is the system } \\
\text { comfortable to be used? }\end{array}$ & 2 & 30 & $\begin{array}{l}11 \\
2 \\
\end{array}$ & 38 & 182 \\
\hline 2 & $\begin{array}{l}\text { Is the system easy to be } \\
\text { used? }\end{array}$ & 1 & 20 & $\begin{array}{l}12 \\
6 \\
\end{array}$ & $\begin{array}{l}16 \\
0 \\
\end{array}$ & 307 \\
\hline 3 & $\begin{array}{l}\text { Does the system give a } \\
\text { beneficial information } \\
\text { to the drivers? }\end{array}$ & 1 & 26 & $\begin{array}{l}13 \\
2\end{array}$ & $\begin{array}{l}14 \\
0\end{array}$ & 299 \\
\hline 4 & $\begin{array}{l}\text { Is the system efficient to } \\
\text { be used by the drivers } \\
\text { rather than those who } \\
\text { are not using the } \\
\text { system? }\end{array}$ & 2 & 42 & $\begin{array}{l}13 \\
5\end{array}$ & $\begin{array}{l}10 \\
0\end{array}$ & 279 \\
\hline 5 & $\begin{array}{l}\text { Is the damaged road data } \\
\text { appropriate with the fact } \\
\text { in real world? }\end{array}$ & 7 & 42 & $\begin{array}{l}12 \\
6\end{array}$ & $\begin{array}{l}92 \\
3\end{array}$ & 267 \\
\hline 6 & $\begin{array}{l}\text { Can the road condition } \\
\text { information system on } \\
\text { your cellphone }\end{array}$ & 1 & 35 & $\begin{array}{l}10 \\
0\end{array}$ & 60 & 196 \\
\hline
\end{tabular}

SD : Strongly Disagree

Dis : Disagree

Ag : Agree

To calculate the result of the questionnaire, the researchers used likert scale from Arikunto [29]. The formula is as the following:

$P=\frac{f}{n}_{x 100}$

Description:

$\mathrm{P}$ : percentage

: questionnaire response frequency total respondents) 


\section{Development of a Road Condition Information System using Augmented Reality Technology on Smartphones}

Table- IV: The Percentage Result Based On Each Criteria

\begin{tabular}{|l|l|l|}
\hline No & Questions & $\begin{array}{l}\text { Percentage per } \\
\text { question \% }\end{array}$ \\
\hline 1 & Is the system comfortable to be used? & 48.92473118 \\
\hline 2 & Is the system easy to be used? & 82.52688172 \\
\hline 3 & $\begin{array}{l}\text { Does the system give a beneficial } \\
\text { information to the drivers? }\end{array}$ & 80.37634 \\
\hline 5 & $\begin{array}{l}\text { Is the system efficient to be used by the } \\
\text { drivers rather than those who are not } \\
\text { using the system? }\end{array}$ & 75 \\
\hline 6 & $\begin{array}{l}\text { Is the damaged road data appropriate } \\
\text { with the fact in real world? }\end{array}$ & 71.77419 \\
\hline Mean & $\begin{array}{l}\text { Can the road condition information } \\
\text { system on your cellphone }\end{array}$ & 52,6 \\
\hline
\end{tabular}

Based on the five questions that have been filled in by 93 respondents, this test obtained an average value of $68 \%$. Based on these criteria, this system gets a pretty good response from the driver. It was welcomed quite well by drivers in Semarang. But based on the percentage results per question, there are two drawbacks to the system. The first lacks convenience when drivers use the system. The second system cannot detect road conditions around the driver because the GPS feature is not activated automatically on some smartphones.

\section{CONCLUSION}

This research produces an road condition information system to help drivers get information about road conditions via smartphone. The road condition information system uses augmented reality technology with a markerless GPS Based Tracking method. This System consists of backend and frontend interfaces. The backend interface is used by Public Works Department employees to import data and monitor road conditions in Semarang City. On the Frontend interface, the road condition information system can display information on road conditions. This interface is used for all drivers in Semarang via a smartphone. The trial of this system includes all drivers in the Semarang city. Based on the results of the questionnaire responded to by 93 respondents, this test obtained an average value of $68 \%$. For further research, it can complement the shortcomings such as adding virtual objects that it are display with real objects and adding navigation to provide alternative directions for system users. A conclusion section is not required. Although a conclusion may review the main points of the paper, do not replicate the abstract as the conclusion. A conclusion might elaborate on the importance of the work or suggest applications and extensions.

\section{ACKNOWLEDGMENT}

The author would like to thank Semarang University, Semarang- Indonesia for support in the present work.

\section{REFERENCES}

1. S. of T. Statistics, Land Transportation Statistics 2018, 1st ed. Indonesia: CBPS RI/BPS-Statistics Indonesia, 2018.

2. D. N. Anggarani and M. Rahardjo, "Hubungan Kepadatan Lalu Lintas Dengan Konsentrasi Cohb Pada Masyarakat Berisiko Tinggi D Sepanjang Jalan Nasional Kota Semarang,”J. Kesehat. Masy., vol. 4, no. 2, pp. 139-148, 2016.

3. L. Abdi, F. Ben Abdallah, and A. Meddeb, "In-Vehicle Augmented
Reality Traffic Information System: A New Type of Communication between Driver and Vehicle," Procedia Comput. Sci., vol. 73, no. Awict, pp. 242-249, 2015.

4. M. B. Ibrahim Abdallah Hag Eltoum, "Velocity based Tracking and Localization System using Smartphones with GPS and GPRS/3G," Int. J. Comput. Appl. (0975 - 8887), vol. 76, no. 11, pp. 41-51, 2013.

5. C. G. Ahmad Ihsan, Nurul Fadillah, "Acehnese traditional clothing recognition based on augmented reality using hybrid tracking method," Indones. J. Electr. Eng. Comput. Sci., vol. 20, no. 2, pp. 1030-1036, 2020.

6. M. A. Huang, Weidong, Alem, Leila, Livingston, Human Factors in Augmented Reality Environments. New York: Springer, 2013.

7. N. D. A. H. Danakorn Nincarean, Mohamad Bin Bilal Ali, "Collaborative Augmented Reality in Education: A Review," in Conference: 2014 International Conference on Teaching and Learning in Computing and Engineering (LaTiCE), 2014, pp. 78-83.

8. G. L. PanosE. Kourouthanassis, Costas Boletsis, "Demystifying the design of mobile augmented reality applications," Multimed. Tools Appl., vol. 74, no. 4, pp. 1-22, 2013.

9. S. Schinke, Torben and Henze, Niels and Boll, "Visualization of off-screen objects in mobile augmented reality," in roceedings of the 12th Conference on Human-Computer Interaction with Mobile Devices and Services, 2010, pp. 313-316.

10. G. Huang, Haosheng and Schmidt, Manuela and Gartner, "Spatia Knowledge Acquisition with Mobile Maps, Augmented Reality and Voice in the Context of GPS-based Pedestrian Navigation: Results from a Field Test," Cartogr. Geogr. Inf. Sci., vol. 39, pp. 107-116, 2013.

11. Jaron Waldman, “Augmented Reality Maps,” US 9.488.488 B2, 2016

12. S. A. and R. F. R. M A Muchtar1, M F Syahputra1, N Syahputra1, "Augmented Reality for Searching Potential Assets in Medan using GPS based Tracking," in Journal of Physics: Conference Series, 2017, vol. 801, no. 1 .

13. I. G. A. Piarsa, I Nyoman; Buana, Putu Wira; Mahasadhu, "Android Navigation Application with Location-Based Augmented Reality," IJCSI Int. J. Comput. Sci. Issues, vol. 13, no. 4, p. 83, 2016.

14. L.-J. C. Te-Lien Chou, "Augmented Reality Smartphone Environment Orientation Application: A Case Study of the Fu-Jen University Mobile Campus Touring System," in Procedia - Social and Behavioral Sciences, 2012, pp. 410-416.

15. J. Santana-ferná and J. Gó, "Design and Implementation of a GPS Guidance System for Agricultural Tractors Using Augmented Reality Technology," pp. 10435-10447, 2010.

16. M. A. Julie Carmigniani, Borko Furht, "Augmented reality technologies, systems and applications," Multimed. Tools Appl., vol. 51, no. 1, pp. 341-377, 2010.

17. Z. Z. QIN Wen-hu, ZHA Jun-yuan, "Study on Artificial Mark Recognition in Augmented Reality," Meas. Control Technol., 2008.

18. W. Cheng, "Using Homography to Improve the Registration Performance of ARTOOLKIT", Microelectronics \& Computer," Microelectron. Comput., pp. 158-159, 2007.

19. D. R. G. Jens Grubert, Augmented Reality for Android Application Development, 1st ed. Birmingham B3 2BP: Packt Publishing Ltd, 2013.

20. J. A. C. Jan Fritz, Paweena U-Thainual, Tamas Ungi, Aaron J Flammang, Gabor Fichtinger, Iulian Iordachita, "Augmented Reality Visualization with Use of Image Overlay Technology for MR Imaging-guided Interventions: Assessment of Performance in Cadaveric Shoulder and Hip Arthrography at 1.5 T," Radiology, vol. 265, no. 1, pp. 254-9, 2012.

21. D. S. Gerhard Schall, Erick Mendez, Ernst Kruijff, Eduardo E. Veas, Sebastian Junghanns, Bernhard Reitinger, "Handheld augmented reality for underground infrastructure visualization," Pers. Ubiquitous Comput., vol. 13, no. 4, pp. 281-291, 2009.

22. L. Madden, Professional Augmented Reality Browsers for Smartphones: Programming for JUNAIO, LAYAR, and WIKITUDE. Wiley Publishing Inc, 2012.

23. Vuforia, "Vuforia." [Online]. Available: https://developer.vuforia.com/. [Accessed: 20-Nov-2019].

24. S. G. Dhiraj Amin, "Comparative Study of Augmented Reality Sdk's," Int. J. Comput. Sci. Appl., vol. 5, no. 1, pp. 11-26, 2015.

Published By:

Blue Eyes Intelligence Engineering and Sciences Publication

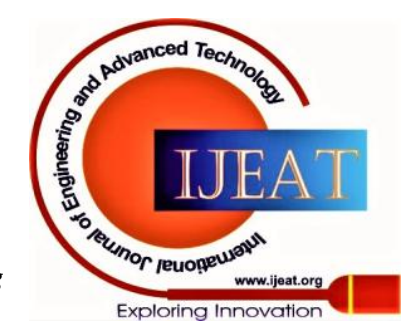


25. T. D. Shunfu Hu, "Online Map Application Development Using Google Maps API, SQL Database, and ASP.NET," Int. J. Inf. Commun. Technol. Res., vol. 3, no. 3, 2013.

26. P. B. Liang Miner, Julio Guerra, "Building multi-layer social knowledge maps with Google Maps API," in Conference: Workshop on Semantic and Adaptive Social Web (SASWeb 2012), 2012.

27. K.Vembandasamy, R.Sasipriya, and E.DeepaP, "Heart Diseases Detection Using Naive Bayes Algorithm,” IJISET - Int. J. Innov. Sci. Eng. Technol., vol. 2, no. 9, pp. 441-444, 2015.

28. E. W. Sandi Fajar Rodiyansyah, "Klasifikasi Posting Twitter Kemacetan Lalu Lintas Kota Bandung Menggunakan Naive Bayesian Classification,” Indones. J. Comput. Cybern. Syst., vol. 6, no. 1, pp. 91-100, 2012.

29. S. Arikunto, Prosedur penelitian: suatu pendekatan praktik, Ed Rev.20. Jakarta: Rineka Cipta, 2010.

\section{AUTHORS PROFILE}

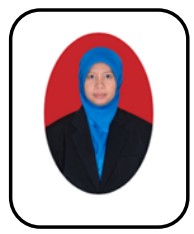

Nur Wakhidah is a lecturer in Department of Informatics Engineering - Semarang University. He received the S.Kom. (2002) in Departement of Informatics Engineering from Dian Nuswantoro Semarang, and M.Cs (2010) in Department of Computer Science and Electronics from Gajah Mada University in Indonesia. He research interests include Artificial Intelligent, Images Processing and Data Mining. She works since 2005, a lecturer in the Department of Informatics Engineering University of Semarang. He has many publishing that included one book, twenty-three Journals paper, and seven conferences paper. Now, he is active as a journal reviewer at Institute For Research And Community Services Semarang University

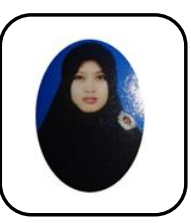

Siti Asmiatun is a lecturer in Informatics Engineering Department - University Semarang and junior member IEEE and Scopus. He receives the S.Kom (2012) in the Department Information System and M.Kom. (2014) with a concentrating education in the field of Game Technology expertise in the Department of Informatics Engineering from the Dian Nuswantoro University in Indonesia. His research interests include games, Augmented Reality, Artificial Intelligent, and Data Mining. He works since 2015, a lecturer in the Department of Informatics Engineering University of Semarang. He has publishing that included two books, thirteen Journals paper, and seven conferences paper. Now, he is active as an accredited journal editor at Transformatika.

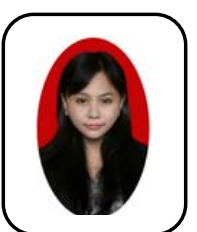

Astrid Novita Putri, Born in Kudus, on November 5 1990, the author completed his undergraduate education at Dian Nuswantoro University, Semarang with concentrating in the field of Information Systems. In 2012 the author received a Superior Scholarship from the Ministry of Education and Culture underwent a Masters program in Informatics Engineering with a concentrating education in the field of Game Technology expertise at Dian Nuswantoro University. Currently, the author as a lecturer at the Faculty of Information and Communication Technology, Informatics Engineering Study Program, University of Semarang, researches the fields of games, augmented reality, data mining, smart cities. Now, the author has undergone doctoral studies at the Faculty of Electrical and Intelligent Information Technology at the Sepuluh Nopember Institute of Technology Surabaya.

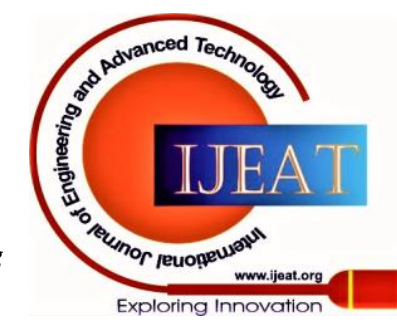

